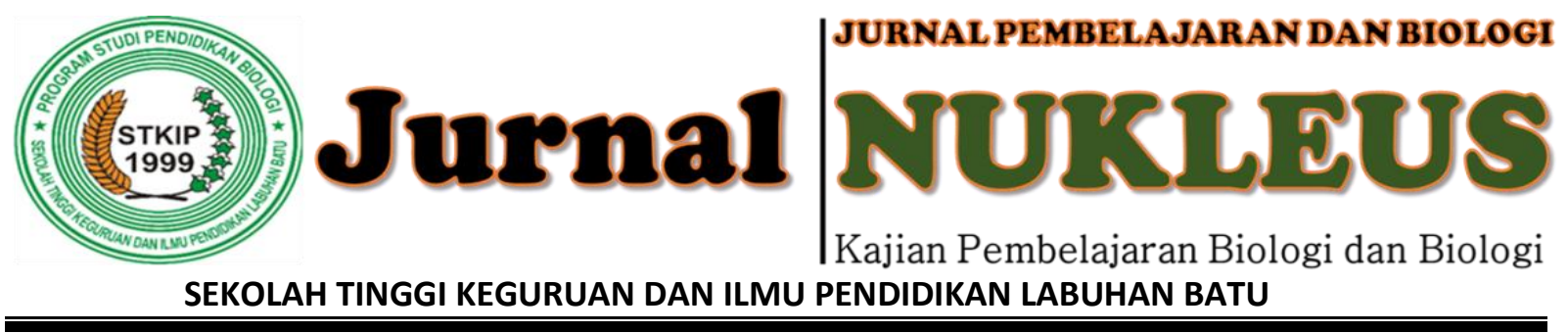

\title{
DISTRIBUSI SPASIAL DAN KARAKTERISTIK HABITAT UDANG KELONG (Penaeus indicus) PADA PERAIRAN EKOSISTEM MANGROVe SICANANG- BELAWAN, SUMATERA UTARA
}

\author{
RIVO HASPER DIMENTA ${ }^{(1)}$, RUSDI MACHRIZAL $^{(1)}, \operatorname{KHAIRUL}^{(1)}$ \\ (1) Pendidikan Biologi, STKIP Labuhan Batu \\ Jalan SM Raja No 126 A, Aek Tapa, Rantauprapat *email: rivohd11@gmail.com
}

\section{Info Artikel}

Riwayat Artikel:

Diterima Desember 2018

Disetujui Januari 2018

Dipublikasikan Februari 2018

\begin{abstract}
Abstrak
Perairan ekosistem mangrove Sicanang-Belawan merupakan salah satu wilayah pasang-surut yang dipengaruhi oleh arus dari sungai Belawan dan arus laut pantai timur Sumatera yang mempengaruhi adanya perbedaan karakteristik habitat yang berdampak pada sebaran kelimpahan udang kelong ( $P$. indicus). Penelitian bertujuan untuk mengetahui distribusi spasial dan karakteristik habitat udang kelong menerapkan metode deskriptif. Pengambilan sampel dilakukan pada bulan September - November 2017 di sekitar perairan ekosistem mangrove SicanangBelawan. Alat tangkap udang menggunakan jaring ambai berbahan nilon polyfilament. Stasiun pengamatan ditentukan menggunakan metode purposive random sampling. Analisa data menggunakan metode statitik multivariabel yang didasarkan pada Analisis Komponen Utama (Principal Component Analysis, PCA) dan Analisis Korelasi (Corresponden Analysis, CA). Hasil analisis PCA menunjukkan bahwa parameter lingkungan membentuk pengelompokkan yang mampu menggambarkan karakteristik habitat udang kelong ( $P$. indicus). Habitat dikelompokan menjadi tiga kelompok karakter, yaitu kelompok habitat dekat daratan (asosiasi stasiun 1, 4 dan 5), kelompok habitat dekat estuaria (asosiasi stasiun 2), dan kelompok habitat dekat aliran sungai besar Belawan (asosiasi stasiun 3). Hasil analisis CA menunjukkan bahwa letak lokasi sampling terbukti mempengaruhi pengelompokkan dari distribusi populasi udang kelong (P.indicus) berdasarkan ukuran, jenis kelamin dan tingkat kematangan gonadnya
\end{abstract}

Kata Kunci: Distribusi Spasial (CA), Karakteristik Habitat (PCA), Penaeus indicus, Sicanang-Belawan

\section{PENDAHULUAN}

Ekosistem mangrove (bakau) adalah ekosistem yang berada di daerah tepi pantai yang dipengaruhi oleh pasang surut air laut sehingga dasarnya selalu tergenang air. Supriharyono (2009) Ekosistem mangrove berada di antara level pasang naik tertinggi sampai level di sekitar atau di atas permukaan laut rata-rata pada daerah pantai yang terlindungi). Manfaat ekosistem mangrove yang berhubungan dengan fungsi fisik seperti Senoadji dan hidayat (2016); Lasibani dan Eni (2009) peredam gelombang, pelindung pantai dari abrasi, gelombang air pasang (rob), tsunami, penahan lumpur dan perangkap sedimen yang diangkut oleh aliran air permukaan. Selain itu, Ekosistem mangrove berperan penting dalam pengembangan perikanan pantai (Heriyanto dan Subiandono, 2012); karena merupakan tempat berkembang biak, memijah, dan membesarkan anak bagi beberapa jenis ikan, kerang, kepiting, dan udang (Kariada dan Andin, 2014; Kordi, 2012;
Djohan, 2007), Jenis plankton sebagai salah satu pakan alami udang di perairan mangrove lebih banyak dibandingkan di perairan terbuka (Qiptiyah, et al, 2008). Hutan mangrove menyediakan perlindungan dan makanan berupa bahan organik ke dalam rantai makan (Pramudji, 2001; Hogarth, 2001). Diantara udang penaeid yang memerlukan dukungan nutrisi ekosistem mangrove tersebut, salah satunya adalah udang kelong (P.indicus).

Sicanang-Belawan merupakan salah satu kawasan ekosistem mangrove yang terletak di pesisir bagian Timur pulau Sumatera, provinsi Sumatera Utara dengan luas total potensi mangrove tercatat $158.637,2 \mathrm{Ha}$, Siringoringo, et al (2017); Dinas Kehutanan Provinsi Sumatera Utara (2011). Berdasarkan informasi dari wawancara dengan nelayan setempat bahwa terjadi penurunan hasil tangkapan di sekitar ekosistem mangrove Belawan dalam 5 tahun terakhir. Buwono (2017) Penurunan hasil 
tangkapan erat kaitannya dengan keberadaan kondisi ekosistem mangrove. Berdasarkan informasi tersebut dan untuk keberlanjutan populasi dan pengelolaan udang maka dipandang perlu melakukan kajian yang berkaitan dengan distribusi populasi udang kelong (Penaeus indicus). Kajian distribusi ini dilakukan untuk memberikan gambaran distribusi spasial dan karakteristik habitat/lingkungan yang berkaitan erat terhadap kehadiran populasi udang ini di alam.

\section{METODE PENELITIAN Waktu dan Tempat}

Penelitian ini dilaksanakan mulai September 2017 sampai November 2017 di sekitar perairan mangrove Sicanang-Belawan, Sumatera Utara. Lokasi penangkapan udang terdiri atas 5 titik stasiun.

\section{Alat dan Bahan}

Adapun alat yang digunakan adalah alat tangkap udang (jaring ambai), jangka sorong, kamera digital, buku acuan identifikasi udang menurut Lovett (1981), Dore \& Frimodt (1987), dan Chaitiamvong \& Supongpan (1992), spidol permanen, senter, coolbox, toples kaca, kotak styrofoam, alat tulis. Bahan-bahan yang digunakan adalah es batu, tisu, plastik, kertas label, buku data, Alkohol $70 \%$ sebagai pengawet sampel udang.

\section{Prosedur Pengambilan Sampel}

Penentuan titik pengambilan sampel ditetapkan dengan metode purposive random sampling) agar memperoleh data yang mewakili lokasi. Pengambilan sampel udang, dilakukan menggunakan jaring ambai berbentuk kerucut yang terbuat dari bahan nilon polyfilament. Detail ukuran jaring ambai yang digunakan adalah bukaan mulut jaring (bentuk persegi berukuran 4,5 $\mathrm{m} \times 4,5 \mathrm{~m}$ ) dengan panjang total jaring (tinggi limas) berukuran $15 \mathrm{~m}$, menurut besar kecilnya ukuran mata jaring (mesh size) terbagi atas empat bagian yang memanjang yaitu bagian depan/sayap $(10 \mathrm{~mm})$, tengah $(15 \mathrm{~mm})$, belakang $(12 \mathrm{~mm})$, dan kantong/cod end $(9 \mathrm{~mm})$. Setiap titik pengambilan sampel dipasang 3 unit jaring per pengamatan dengan waktu pengambilan sampel dilakukan secara stastis/menetap, pada saat pasang/surut dengan peletakan posisi jaring melawan pergerakan arus air (mengikuti kebiasaan nelayan setempat). Pengambilan data mangrove, dilakukan dengan metoda pengukuran Transek Garis Berpetak (Line Transect Plot) (Kusmana, 1997; Ardhana, 2012) dan identifikasi mangrove mengacu buku Noor et al (2006). Pada saat yang bersamaan juga dilakukan pengukuran nilai parameter fisika kimia lingkungan meliputi data salinitas, suhu, kecepatan arus, kedalaman, kecerahan, TSS, oksigen terlarut, $\mathrm{pH}$, phospat,nitrat, fraksi substrat yang dianalisis secara Insitu dan Exsitu, detail pengukuran dapat dilihat pada tabel 1 .

\section{Analisa Data \\ Analisa Distribusi Spasial Udang (P.indicus) Kaitannya Dengan Karakteristik Fisik-Kimia Lingkungan}

Evaluasi kuantitatif terhadap sebaran populasi udang antar stasiun pengamatan dan kaitannya terhadap karakteristik fisik-kimia lingkungan dilakukan menggunakan Analisis Faktorial Korespondensi atau CA (Correspondence Analysis) (Bengen 2002) yang terdapat pada software XL-Stat. Analisis ini merupakan salah satu bentuk analisis statistik multivariable yang didasarkan pada matriks data $\mathrm{i}$ baris (stasiun penelitian) dan $\mathrm{j}$ kolom (jenis kelamin, kelas ukuran, dan tingkat kematangan gonad). Kelimpahan udang menurut modalitas dari tiap klasifikasi tersebut, yang ditemukan pada tiap stasiun penelitian terdapat pada baris ke-i dan kolom ke-j. Dengan demikian, matriks data yang digunakan merupakan tabel kontingensi stasiun penelitian dengan modalitas jenis. Dalam tabel kontingensi, i dan $\mathrm{j}$ mempunyai peranan yang simetrik yakni membandingkan unsur-unsur i (untuk tiap j) sama dengan membandingkan hukum probabilitas bersyarat yang diestimasi dari $\mathrm{nij} / \mathrm{ni}$ (untuk masing-masing $\mathrm{nij} / \mathrm{ni}$ ), dimana $\mathrm{ni}=$ jumlah i yang memiliki semua karakter $j$, dan $n j=$ jumlah jawaban karakter j. Selanjutnya pengukuran kemiripan antara dua unsur I1 dan I2 dari I dilakukan melalui pengukuran jarak chikuadrat $\left(X^{2}\right)$ (Bengen, 2000). Jarak Chi-kuadrat $\left(X^{2}\right)$ dihitung dengan rumus:

$$
\mathrm{X}^{2}=\frac{\mathrm{n} \Sigma \mathrm{X}^{2}}{\mathrm{~N}}-\mathrm{N}
$$

Tabel 1. Parameter yang diukur, satuan, alat/bahan/metode yang digunakan, dan tempat pengukuran

\begin{tabular}{|c|c|c|c|}
\hline Parameter & Satuan & $\begin{array}{l}\text { Alat/bahan/metode } \\
\text { yang digunakan }\end{array}$ & $\begin{array}{l}\text { Tempat } \\
\text { Pengukuran }\end{array}$ \\
\hline Suhu Air & ${ }^{\circ} \mathrm{C}$ & Termometer $\mathrm{Hg}$ & In-situ \\
\hline Salinitas Air & $\%$ & Hand Refraktometer & In-situ \\
\hline $\mathrm{pH}$ Air & - & $\mathrm{pH}$ meter & In-situ \\
\hline Kecerahan & $\mathrm{Cm}$ & Keping Sechi & In-situ \\
\hline DO (Oksigen Terlarut) & $\mathrm{Mg} / \mathrm{L}$ & Titrasi Winkler & In-situ \\
\hline Kecepatan Arus & $\mathrm{m} / \mathrm{s}$ & Tabung sediment trap & Laboratorium \\
\hline $\mathrm{BOD}_{5}$ & $\mathrm{Mg} / \mathrm{L}$ & Titrasi Winkler & Laboratorium \\
\hline Kandungan Total Suspended Solid (TSS) & $\mathrm{Mg} / \mathrm{L}$ & Gravimetri & Laboratorium \\
\hline Kandungan $\mathrm{NO}_{3} \& \mathrm{PO}_{4}$ & $\mathrm{Mg} / \mathrm{L}$ & Spektrofometer & Laboratorium \\
\hline Fraksi Substrat & - & Metode Abu & Laboratorium \\
\hline Kerapatan Mangrove & Ind/Ha & Metode Kuadrat & In-situ \\
\hline Kelimpahan Populasi Udang (P.indicus) & Ind $/ \mathrm{m}^{2}$ & Jaring Udang & In-situ \\
\hline
\end{tabular}




\section{Analisa Karakteristik Habitat Udang Kelong (P.indicus) Berdasarkan Parameter Fisik- Kimia Lingkungan}

Pengelompokan Karakteristik habitat udang pada tiap stasiun penelitian berdasarkan variasi parameter biofisik kimia lingkungan, Pengelompokkan tersebut dianalisa menggunakan suatu pendekatan analisis statistik multivariabel yang didasarkan pada analisis komponen utama (Principal Component Analysis/PCA) (Bengen 2002) yang terdapat pada software XL-Stat. Analisis ini merupakan metode statistik deskriptif yang bertujuan untuk menampilkan informasi maksimum data dalam bentuk grafik. Data parameter biofisik-kimia yang diukur tidak berunit pengukuran dan ragam yang sama, sehingga sebelum dilakukan analisis komponen utama, data tersebut harus dinormalisasikan melalui pemusatan dan pereduksian. Pada prinsipnya PCA menggunakan pengukuran jarak Euclidean yang mengacu pada data. Semakin kecil jarak euclidean antar 2 stasiun, semakin mirip karakteristik biofisik kimia lingkungan kedua stasiun tersebut, demikian pula sebaliknya. Jarak euclidean didasarkan pada rumus sebagai berikut (Bengen, 2000):

$$
d^{2}\left(i, i^{\prime}\right)=\sum_{j=1}^{p}\left(X_{i j}-X_{i j}\right)^{2}
$$

HASIL DAN PEMBAHASAN

Distribusi Spasial Udang Kelong (P.indicus) Kaitannya Dengan Karakteristik Lingkungan Distribusi Spasial Udang Kelong Berdasarkan Jenis Kelamin dan Kelas Ukuran Hasil analisis menggunakan Correspondence Analysis (Gambar 1.) didapatkan bahwa informasi distribusi spasial udang kelong terpusat pada 2 sumbu utama yang masingmasing menjelaskan sebesar $74,98 \%$ dan 17,03 $\%$ dari ragam total $(92,00 \%)$. Hasil analisis juga mengelompokkan titik-titik pengamatan atas 3 kelompok besar yang mempunyai keterkaitan erat antara kelompok udang kelong menurut kelas ukuran dan jenis kelamin (jantan berukuran kecil, jantan berukuran sedang, jantan berukuran besar, betina berukuran kecil, betina berukuran sedang, betina berukuran besar) dengan stasiun pengamatan yang berbeda karakteristik biofisikkimia.

Kelompok I yang terdiri atas stasiun 1 dan 4 memiliki dominasi kelimpahan udang kelong dengan jantan berukuran kecil dan besar serta, betina berukuran sedang yang tinggi. Kelompok II ini berada pada stasiun 2 dan 5 dengan dominasi kelimpahan udang $P$. indicus dengan jumlah jantan berukuran kecil, serta betina berukuran kecil dan besar yang tinggi. Kelompok III yang pada stasiun 3 memiliki dominasi kelimpahan udang kelong dengan jumlah betina berukuran sedang, serta jantan berukuran besar dan sedang yang tinggi.

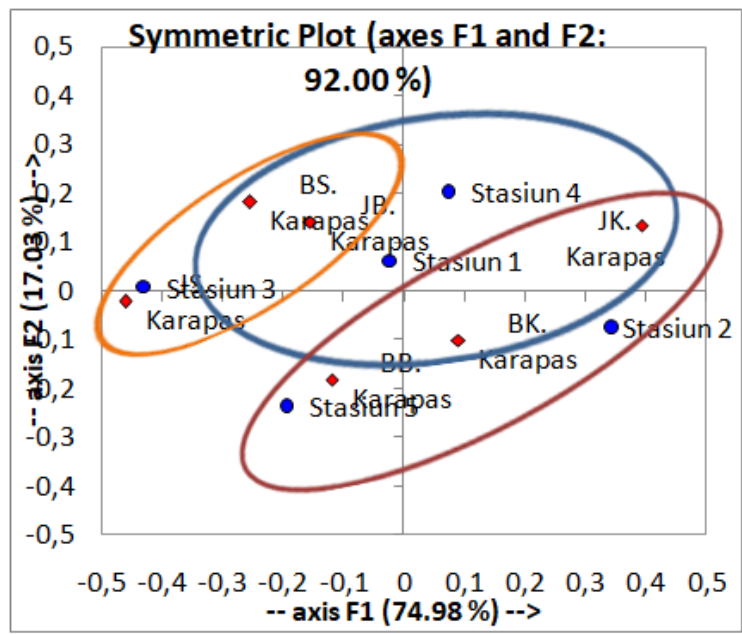

Keterangan :

JK. Karapas = Jantan, Panjang Karapas Kecil

BK.Karapas $=$ Betina, Panjang Karapas Keci

JS.Karapas = Jantan, Panjang Karapas Sedang

BS.Karapas = Betina, Panjang Karapas Sedang

JB. Karapas = Jantan, Panjang Karapas Besar

BB. Karapas = Betina, Panjang Karapas Besar

Gambar 1. Diagram Analisis Koresponden (CA) Keterkaitan Stasiun Pengamatan Dengan Distribusi Udang Kelong ( $P$. indicus) Berdasarkan Kelas Ukuran dan Jenis Kelamin

Dari gambar 1. dapat disimpulkan bahwa kelimpahan udang berdasarkan jenis kelamin dan kelas ukuran berpengaruh terhadap kondisi fisikkimia lingkungan (contohnya: fraksi substrat) yang terdapat pada masing-masing stasiun pengamatan di ekosistem mangrove Belawan, dimana kelimpahan jantan lebih banyak ditemukan pada habitat yang memiliki fraksi substrat pasir yang tinggi, sedangkan betina ditemukan melimpah pada habitat yang memiliki fraksi substrat lumpur dan pasir. Wijaya dan Pratiwi (2011) substrat dasar yang berbeda akan terdapat perbedaan ukuran dan kepadatan udang yang ada pada kawasan tersebut. Menurut Pramonowibowo et al. (2007) berdasarkan siklus hidupnya, fase larva dan juvenil udang akan hidup diperairan yang 
dangkal dan seiring dengan perkembangan tubuhnya maka udang akanmenyebar ke perairan yang lebih dalam serta akan memilih suatu kawasan yang substrat dasarnya sesuai dengan kehidupannya. Holthuis (1980) menyatakan habitat udang $P$. indicus berada pada kedalaman 2 - 90 meter pada dasar perairan atau lumpur berpasir. Ketika dewasa banyak ditemukan di laut dan untuk tahap juvenil (anakan) sering ditemukan di muara laut. Menurut Kordi (2010) Udang kelong hidup bergerombol dalam jumlah besar di perairan dengan dasar berlumpur atau lumpur berpasir.

Penggunaan analisa Coresponden Analysis (CA) juga pernah dilakukan oleh Wijaya dan Pratiwi (2011) dalam mendeskripsikan kelimpahan keanekaragaman krustasea pada perairan MatasiriKalimantan Selatan.

Distribusi Spasial Udang Kelong ( $P$. indicus) Berdasarkan Tingkat Kematangan Gonad

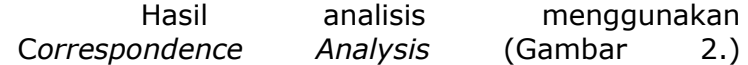
mendapatkan bahwa informasi distribusi spasial udang kelong terpusat pada 2 sumbu utama yang masing-masing menjelaskan sebesar $73,70 \%$ dan $24,18 \%$ dari ragam total $(97,89 \%)$. Hasil analisis juga mengelompokkan titik-titik pengamatan atas 3 kelompok besar yang mempunyai keterkaitan erat antara kelompok udang kelong menurut tingkat kematangan gonad (TKG I, TKG II, TKG III, TKG IV) dengan stasiun pengamatan yang berbeda karakteristik biofisik kimia.

Kelompok 1 yang terdiri atas stasiun 1,4 dan 5 dicirikan dengan melimpahnya udang kelong betina kategori TKG II dan III. Dominasi TKG II dan III pada 3 stasiun tersebut kemungkinan disebabkan oleh lokasi tersebut merupakan lokasi yang masihdianggap mendukung udang dewasa $(P$. Indicus) dalam fase kawin atau bertelur, dimana kondisi fraksi substrat liat dan debu memudahkan hewan bentik ini untuk menggali lubang pada dasar perairan.

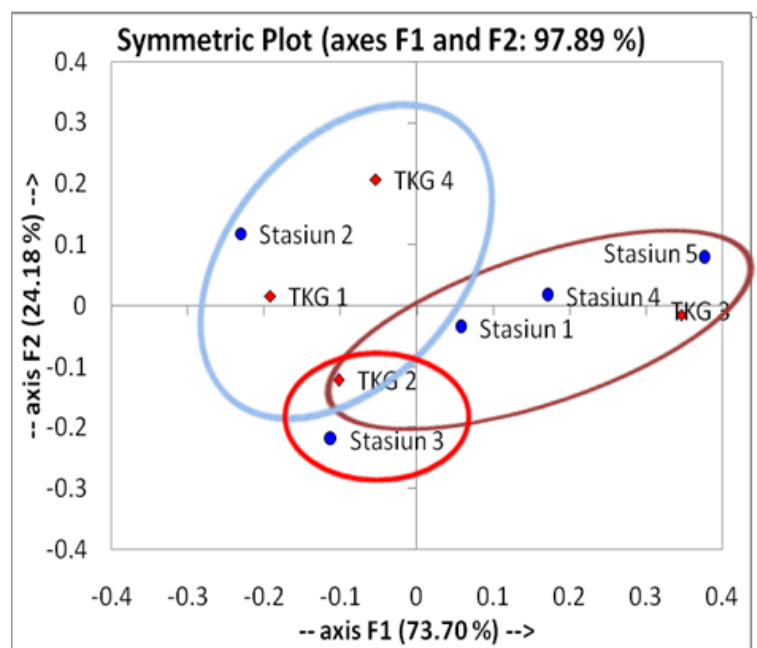

Gambar 2. Diagram Analisis Koresponden $(C A)$ Keterkaitan Stasiun Pengamatan Dengan Distribusi Udang Kelong ( $P$. indicus) Berdasarkan Tingkat Kematangan Gonad

Kelompok 2 terdiri atas stasiun 3 dicirikan oleh melimpahnya udang kelong betina TKG II. Letak lokasi sampling stasiun 3 yang berada di sekitar perairan terdekat dengan muara laut Belawan menyebabkan nilai salinitas air tinggi. Kehadiran dominasi udang betina dengan TKG II yang tertangkap pada stasiun 3 ini diduga merupakan individu yang sedang berusaha menuju/meninggalkan wilayah mangrove.

Kelompok 3 yang terdiri atas stasiun 2 yang bercirikan melimpahnya udang betina dengan TKG I, II dan IV. Kelompok ini memiliki kelimpahan udang udang betina dengan ragam tingkat kematangan gonad (TKG I, II dan IV) terbanyak, hal ini kemungkinan dipengaruhi oleh stasiun 2 yang merupakan lokasi dengan kategori zona alami (minim gangguan/aktivitas antropogen: masyarakat sekitar). Selain itu, Susiana (2015); Ginting et al (2017) tingginya keanekaragaman vegetasi mangrove karena memiliki fluktuasi unsur hara yang baik (saat pasang-surut) memungkinkan memiliki tingkat kerapatan jenis mangrove tinggi, dan ragam jenis plankton yang tinggi menjadikan lokasi ini sebagai lokasi yang paling optimum untuk mendukung tumbuh kembang udang dewasa yang akan memasuki fase siap kawin ataupun bertelur.

Karakteristik Habitat Udang Kelong (P.indicus) Berdasarkan Parameter Fisik-Kimia Lingkungan

Karakteristik habitat udang kelong yang dianalisis menggunakan Principal Component Analysis (PCA) menunjukkan informasi penting yang menggambarkan korelasi antar parameter terpusat pada dua sumbu utama (F1 dan F2). Ragam karakteristik habitat udang kelong menurut stasiun penelitian berdasarkan parameter biofisik kimia lingkungan dapat dijelaskan melalui dua sumbu utama (F1 dan F2), masing-masing sebesar $55,11 \%$ dan $30,67 \%$ (Gambar 3.) dari ragam total (sebesar 85,77\%). Kualitas representasi dari variabel pada sumbu dievaluasi secara langsung dengan cara melihat jarak variabel dengan sumbu, dimana semakin kuat korelasinya (positif atau negatif) maka semakin dekat jarak variabel tersebut dengan sumbu (Bengen, 2000). Dari gambar diagram sebaran stasiun penelitian berdasarkan parameter biofisik kimia lingkungan pada sumbu 1 dan 2 ini, membentuk 3 


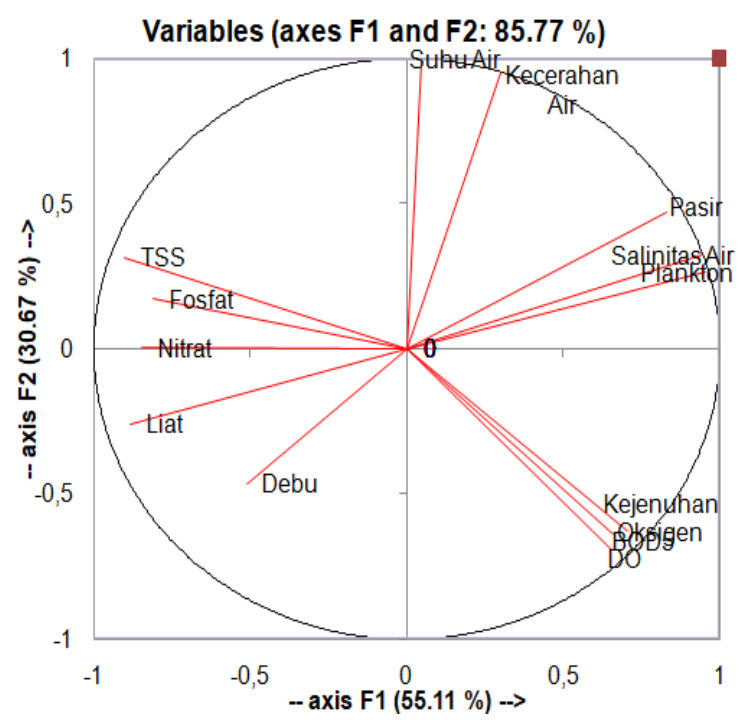

Gambar 3. Diagram Lingkaran Korelasi Antar Parameter Biofisik Kimia Lingkungan Pada Sumbu Faktorial F1 (Sumbu Horizontal) Dan Sumbu F2 (Sumbu Vertikal)

Kelompok I terdiri atas stasiun 1, 4, dan 5 yang memiliki habitat dengan nilai TSS (188.3 $\mathrm{mg} / \mathrm{l})$, nitrat $(0.25 \mathrm{mg} / \mathrm{l})$, fosfat $(0.11 \mathrm{mg} / \mathrm{l})$, serta substrat liat $(31.44 \%)$ dan debu $(52 \%)$ yang tinggi. Kelompok ini berkontribusi menyusun sumbu F1 negatif. Lokasi stasiun 1 dekat dengan pemukiman masyarakat dan stasiun 4 berada pada perkebunan kelapa sawit, kedua lokasi ini banyak mendapat pengaruh ontogenik (aktivitas masyarakat) sehingga memiliki kadar nitrat dan posfat yang tinggi, sedangkan nilai TSS, fraksi substrat liat dan fraksi debu disebabkan oleh lokasi ini agak menjorok kedalam menuju daratan, serta memungkinkan dominasi kelimpahan udang jantan berukuran kecil dan besar, serta betina berukuran sedang untuk menemukan habitat yang sesuai karena dipengaruhi oleh ketersediaan pakan yakni plankton yang cukup tinggi keanekaragamannya.

$$
\text { Kelompok II yang berada pada stasiun } 2
$$
memiliki habitat dengan nilai salinitas air (25.39 \%o), kelarutan oksigen (5.11 mg/l), kejenuhan oksigen $(67 \%)$, BOD $_{5}(4.09 \mathrm{mg} / \mathrm{l})$, kelimpahan plankton (77449 ind/I) dan substrat pasir (56.56 \%) yang tinggi. Kelompok ini berkontribusi menyusun sumbu F1 positif. Letak stasiun 2 berada relatif lebih menuju Sungai Belawan yang membawa aliran air tawar dan sedimen, sehingga kondisi salinitas pada perairan menjadi lebih rendah (tawar) sehingga kandungan nutrien menjadi tinggi dibandingkan stasiun yang lainnya, selain itu kondisi kerapatan jenis mangrove juga berpengaruh pada kelimpahan udang kelong. Poedjiraharjoe et al (2017) Sebaran jenis mangrove dipengaruhi oleh salinitas, suhu, $\mathrm{pH}$, dan tebal lumpur. Wijaya dan Pratiwi (2011) Pasokan air tawar dan sedimen dari daratan atau aliran sungai juga sangat mempengaruhi kehidupan udang penaeid. Kelimpahan krustasea sangat dipengaruhi oleh parameter salinitas, kecerahan, dan kedalaman.

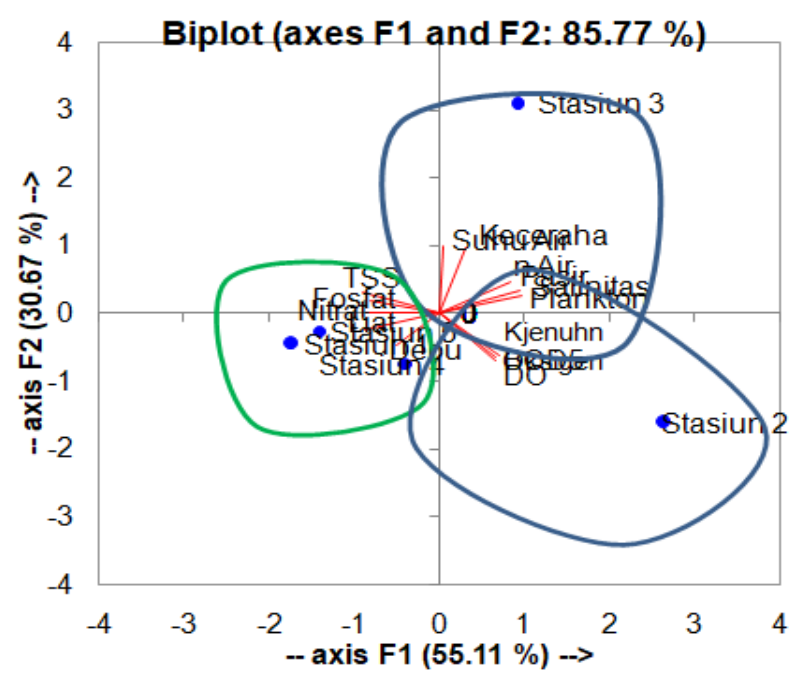


Gambar 4. Diagram Representasi Karakter Dan Distribusi Stasiun Penelitian Berdasarkan Parameter Biofisik Kimia Lingkungan pada Sumbu 1 dan Sumbu 2

Kelompok III pada stasiun 3 ini berkontribusi menyusun sumbu F2 positif, yang memiliki karakteristik lingkungan dengan nilai suhu air $\left(30.58{ }^{\circ} \mathrm{C}\right)$, kecerahan $(97.56 \mathrm{~cm})$, salinitas air $(25.39 \%)$, kelimpahan plankton (77449 ind/I) dan substrat pasir $(56.56 \%)$ yang tinggi. Diagram sebaran pada seluruh stasiun tampak pada gambar 4.

Romimohtarto dan Yuwana (2001); Alfitriatussulus (2003); Pratiwi (2010) Berdasarkan penelitian krustasea di perairan Indonesia, kisaran suhu optimal untuk krustasea adalah $28-30{ }^{\circ} \mathrm{C}$, salinitas optimum berkisar 23-32\% dan $\mathrm{pH}$ optimum adalah 7,4-8,5. Poedjiraharjoe et al (2017) menggunakan analisa PCA dalam mengetahui karakteristik lingkungan yang mempengaruhi distribusi mangrove di Pemalang, dimana dari hasil diketahui bahwa sebaran jenis mangrove dipengaruhi oleh salinitas, suhu, $\mathrm{pH}$, dan tebal lumpur.

\section{KESIMPULAN}

Dari penelitian ini dapat diperoleh simpulan bahwa analisa hubungan distribusi spasial udang kelong (berdasarkan kelas ukuran, jenis kelamin dan tingkat kematangan gonad) terhadap karakteristik lingkungan (jenis mangrove, plankton dan parameter fisik-kimia) pada setiap stasiun membentuk 3 kelompok besar. Stasiun 1, 4 dan 5 membentuk kelompok pertama (I) dengan dominasi kelimpahan udang jantan berukuran kecil dan besar, serta betina berukuran sedang, kelompok ini dicirikan oleh karakteristik lingkungan berupa kelimpahan plankton (genus Biddulphia, Coscinosdiscus, Ceratium, Diatoma, Oscillatoria, Cyclops, Brachionus, Tabellaria, Gonatozygon, Melosira, Chaetoceros, Thalassionema, Odontella, Skeletonema, Navicula, Closteriopsis, Fragillaria, Thalassiothrix), kelimpahan mangrove (Jenis $A$. alba, S. alba, E. agallocha, N. fruticans, $H$. littoralis), serta karakter habitat yang memiliki nilai TSS, nitrat, fosfat, fraksi substrat liat dan debu.

Kelompok ke-II (Dua) berada pada stasiun 2 dengan dominasi kelimpahan udang betina berukuran kecil dan besar, Parameter biologi yang menjadi penciri kelompok ini adalah kelimpahan plankton (genus Gonatozygon, Melosira, Chaetoceros, Cyclops, Thalassionema, Odontella, Skeletonema, Ditylum, Dinophysis, Lauderia, Closteriopsis, Fragillaria, Thalassiothrix, Nitzchia, Closterium), serta Kelimpahan jenis mangrove $(H$. littoralis, A. alba, A. marina, S. alba, $S$. caseolaris, $L$. racemosa, $R$. apiculata, $N$. fruticans), dan karakteristik habitat (fisik-kimia) dengan ciri memiliki kelarutan oksigen, kejenuhan oksigen, $\mathrm{BOD}_{5}$, suhu air, kecerahan, salinitas air, kandungan TSS, nitrat, fosfat, juga fraksi substrat pasir dan liat yang tinggi.

Kelompok III (Tiga) yang berada pada stasiun 3 memiliki dominasi kelimpahan betina dan jantan berukuran sedang, kelompok ini didukung oleh karakter lingkungan berupa kelimpahan plankton (genus Bacteriastrum, Chlorococcum, Diaptomus, Volvox, Thalassiosira, Ulothrix, Rhizosolenia, Cerataulina, Coscinodiscus, Ceratium, Asterionella, Protoperidinium, Euglena), serta Kelimpahan mangrove (Jenis B. gymnorrhiza, $R$. mucronata, $L$. racemosa, $R$. apiculata, $A$. marina, S. alba, S. caseolaris, N. fruticans), serta ciri karakteristik habitat yang memiliki nilai suhu air, kecerahan, salinitas air, juga fraksi substrat pasir yang tinggi dimana hal ini dipengaruhi letak lokasi stasiun 3 ini berada paling dekat menuju muara laut Belawan.

Dari pengelompokkan berdasarkan analisis $C A$ dapat diketahui bahwa letak lokasi sampling terbukti mempengaruhi pengelompokkan populasi udang kelong (P.indicus) berdasarkan ukuran, jenis kelamin dan tingkat kematangan gonadnya. Dan dari hasil analisa PCA dapat disimpulkan bahwa parameter lingkungan membentuk pengelompokkan yang mampu menggambarkan karakteristik suatu habitat hewan, dimana pengelompokkan parameter lingkungan mempengaruhi kelimpahan dari populasi udang kelong pada ekosistem mangrove Sicanang-Belawan.

\section{DAFTAR PUSTAKA}

Ardhana, I.P.G. 2012. Ekologi Tumbuhan. Udayana University Press. Universitas Udayana. Denpasar.

Bengen, D.G., 2000. Sinopsis Ekosistem dan Sumberdaya Alam Pesisir. Bogor: Institut Pertanian Bogor.

Buwono, R.Y. 2017. Identifikasi dan Kerapatan Ekosistem Mangrove di Kawasan Teluk Pangpang Kabupaten Banyuwangi. Samakia: Jurnal Ilmu Perikanan, 8 (1): 32-37

Chaitiamvong, S., Supongpan M. 1992. A Guide to Penaeid Shrimp Found in Thai Water. Australian Institute of Marine Science. Townsville, Australia.

Dinas Kehutanan Sumatera Utara. (2011). Naskah Review Peta Potensi Mangrove 2011. Data Statistik Balai Pengelolaan Hutan Mangrove Wilayah II. Medan.

Djohan, T.S., 2007. Distribusi Hutan Bakau di Laguna Pantai Selatan Yogyakarta. Jurnal Manusia dan Lingkungan, 14(1):15-25.

Dore, I., Frimodt C. 1987. An Illustrated Guide To Shrimp Of The World. Library of Congress Catalog Card Number 87-13991. Hongkong.

Heriyanto, N.M., Subiandono, E., 2012. Komposisi dan Struktur Tegakan, Biomasa, dan Potensi Kandungan Karbon Hutan Mangrove di Taman Nasional Alas Purwo. Jurnal Penelitian Hutan dan Konservasi Alam, 9(1): 23-32.

Hogarth, P.J., 2001. The Biology of Mangroves (Biology of Habitats). Oxford Univesity Press. Oxford.

Kariada, T.M., Andin, I., 2014. Peranan Mangrove sebagai Biofilter Pencemaran Air Wilayah Tambak Bandeng, Semarang. Jurnal Manusia dan Lingkungan, 21(2):188-194.

Kordi, M.G.H. (2012). Ekosistem Mangrove: Potensi, Fungsi dan Pengelolaan. Cetakan Pertama. 
Penerbit Rineka Cipta. Jakarta.

Kusmana, C. 1997. Metode Survey Vegetasi. Institut Pertanian Bogor. Bogor.

Lasibani S.M., Eni, K., 2009. Pola Penyebaran Pertumbuhan "Propagul" Mangrove Rhizophoraceae di Kawasan Pesisir Sumatera Barat. Jurnal Mangrove dan Pesisir, 10(1):33-38.

Lovett, D.L. 1981. A Guide to The Shrimp, Prawns, Lobster, and Crabs of Malaysia and Singapore. Faculty of Fisheries and Marine Science. University Pertanian Malaysia. Selangor-Malaysia.

Noor, Y.R., Khazali M., Suryadiputra I.N.N. 2006. Panduan Pengenalan Mangrove Di Indonesia. Cetakan Kedua. PHKA/WI-IP. Bogor.

Pramonowibowo, A. Hartoko \& A. Ghofar. 2007. Kepadatan udang putih (Penaeus merguiensis De Man) di Sekitar Perairan Semarang. Jurnal Pasir Laut, 2(2): 18-29.

Pramudji. 2001. Ekosistem Hutan Mangrove Dan Peranannya Sebagai Habitat Berbagai Fauna Aquatik. Oseana, Volume 26(4):13-23

Poedjiraharjoe, E., Marsono, D., Wardhani, FK. 2017. Penggunaan Principal Component Analysis dalam Distribusi Spasial Vegetasi Mangrove di Pantai Utara Pemalang. Jurnal Ilmu Kehutanan. Vol 11(1): 29-42

Senoaji G., Hidayat, MF . 2016. Peranan Ekosistem Mangrove Di Pesisir Kota Bengkulu Dalam Mitigasi Pemanasan Global Melalui Penyimpanan Karbon. J. Manusia dan Lingkungan, Vol. 23, No. 3: 327-333

Siringoringo, Y. N., Yunasfi., Desrita. (2017). Struktur Komunitas Mangrove Di Hutan Mangrove Kelurahan Belawan Sicanang Kecamatan Medan. Jurnal Aquacoastmarine. Vol 5 (2): 1-7.

Supriharyono, 2009. Konservasi Ekosistem Sumberdaya Hayati di Wilayah Pesisir dan Laut Tropis. Pustaka Pelajar. Yogyakarta.

Susiana, 2015. Analisis Kualitas Air Ekosistem Mangrove Di Estuari Perancak, Bali. Jurnal Ilmiah agribisnis dan Perikanan (agrikan UMMU-Ternate) Volume 8 Edisi 1: 42-49

Qiptiyah, M., Halidah., Rakman, M.A., 2008. Struktur Komunitas Plankton di Perairan Mangrove dan Perairan Terbuka di Kabupaten Sinjai, Sulawesi Selatan. Jurnal Penelitian Hutan dan Konservasi Alam, Vol 5(2):137-143. 